\section{Genotypic Variability in Staminate Flower and Pollen Grain Production of Diploid Watermelons}

\author{
Michael S. Stanghellini ${ }^{1}$ \\ Department of Extension Specialists, Rutgers University, Marucci Center, \\ 125A Lake Oswego Road, Chatsworth, NJ 08019
}

\author{
Jonathan R. Schultheis ${ }^{2}$ \\ Department of Horticultural Science, Box 7609, North Carolina State University, \\ Raleigh, NC 27695
}

Additional index words. Citrullus lanatus, triploid watermelon, seedless, pollenizer, male reproductive output

\begin{abstract}
In 1999 and 2000, a total of 27 diploid watermelon [Citrullus lanatus (Thunb.) Matsum. \& Nakai] cultivars and advanced breeding lines (hereafter referred to as cultigens) were evaluated for staminate flower and pollen grain production to assess their potential to serve as pollenizers (pollen source plants) in triploid watermelon production systems. Male reproductive output (staminate flower and pollen production) was quantified during the peak flowering and fruit setting phase of the cultigens under field conditions. The number of staminate flowers produced per plant per day, number of pollen grains produced per flower, and total number of pollen grains produced per plant per day (staminate flowers per plant $x$ pollen grains produced per flower) differed greatly among cultigens (for all tests, $P<0.01$ ). Staminate flower production by cultigens differed by year $(P<0.0029)$ and days within years $(P=0.0225)$, but pollen production between years by cultigens was stable $(P=0.4841)$. Total male reproductive output ranged from 134,206 pollen grains per plant per day for ' Jamboree' to 321,905 pollen grains per plant per day for 'Summer Flavor 500'. These studies demonstrate the genotypic variability in watermelon male reproductive output potential, and may assist growers in choosing a good diploid pollenizer for triploid watermelon production.
\end{abstract}

Triploid (seedless) watermelon [Citrullus lanatus (Thunb.) Matsum. \& Nakai] production requires the planting of diploid (seeded) watermelon cultivars to serve as pollen source plants (pollenizers), with current production practices recommending that $20 \%$ to $33 \%$ of the field space be occupied by diploid pollenizers $(2: 1$ to $4: 1$ triploid:diploid) (Fiacchino and Walters, 2003; Maynard and Elmstrom, 1992; Rhodes et al., 1997). This is because staminate triploid flowers do not produce sufficient viable pollen to adequately fertilize pistillateflowers, yet seedless fruit formation is dependent on hormones suppliedbypollen tube growth andovule fertilization (Elmstrom and Maynard, 1990; Rhodes et al., 1997; Robinson and Decker-Walters, 1997). The total or near lack of mature seeds in triploid fruit is due to female sterility, whereby ovules abort shortly after fertilization (Kihara, 1951).

Received for publication 16Apr. 2004. Accepted for publication 29 Sept. 2004. We gratefully acknowledge the technical assistance of Dennis Adams, the assistance of CCRS personnel at Clayton, N.C., the financial support and/or seed donated from participating seed companies, and the donations of black polyethylene mulch by North Carolina Plastic Products (Morganton, N.C.) and drip irrigation tape by Roberts Irrigation Products, Inc (San Marcos, Calif.). Mention of a trademark, proprietary product, or vendor does not constitute a guarantee or warranty of the product by the NJARS or NCARS and does not imply its approval to the exclusion of similar products or vendors not mentioned.

${ }^{1}$ To whom reprint requests should be addressed; e-mailmikes@aesop.rutgers.edu.

2E-mail jonathan_schultheis@ncsu.edu.
In many areas of the U.S., seedless watermelons have a greater consumer demand than seeded fruit (Karst, 1990; Marr and Gast, 1991). Thus, growers are interested in optimizing the type and density of pollenizers to maximize field space devoted to the production of the more valuable triploid fruit. Recently, NeSmith and Duval (2001) found that triploid fruit set decreased considerably when the distances between pollenizers and triploid plants exceeded $4.6 \mathrm{~m}$. Similarly, Fiacchino and Walters (2003) evaluated two pollenizers and three pollenizer densities $(11 \%, 20 \%$, and $33 \%)$ for their effect on triploid fruit set. They concluded that 'Crimson Sweet' was a better pollenizer than 'Fiesta', and that a pollenizer density of $20 \%$ to $33 \%$ was better than $11 \%$.

Another approach for maximizing triploid plant field space may be to choose pollenizers that produce large quantities of pollen, thereby potentially reducing the number of pollenizer plants needed. The objectives of our study was to compare staminate flower and pollen grain production of representative diploid watermelon cultigens, and to evaluate the potential of these cultigens to serve as triploid watermelon pollenizers. Specifically, we examined 1) the number of staminate flowers produced per plant per d, 2) the number of pollen grains produced per staminate flower, and 3) male reproductive output, which we considered to be the product of 1 and 2 for each cultigen. With this information, we developed recommendations and a procedure for evaluating pollenizer candidates for use in triploid watermelon production systems.
Cultural practices. Experiments were conducted at the Central Crops Research Station in Clayton, N.C., Soil type in both years was Norfolk loamy sand (fine-loamy, kaolinitic, thermic typic kandiudults) (N.C. Agricultural Research Service et al., 1981). Nitrogen and potash $\left(\mathrm{K}_{2} \mathrm{O}\right)$ were broadcast and disk incorporated $\left(224 \mathrm{~kg} \cdot \mathrm{ha}^{-1}\right.$ of $\left.15 \mathrm{~N}-0 \mathrm{P}-40 \mathrm{~K}\right)$ before fumigation with 1,3-dicholoropropene and chloropicrin (Telone C-17 at $93 \mathrm{~L} \cdot \mathrm{ha}^{-1}$ ). Immediately after fumigation, rows within plots were covered with black plastic $(1.25 \mathrm{~mm})$ (Climagro; St. Laurent, Quebec, Canada) and a single drip-irrigation tube (Roberts Irrigation Products, Inc., San Marcos, Calif.) was placed just beneath the soil surface in the center of each bed. Tubes were $8 \mathrm{~mm}$ thick with a $30.5-\mathrm{cm}$ emitter spacing that provided an average water output of $3 \mathrm{~L} \cdot \mathrm{m}^{-1} \cdot \mathrm{min}^{-1}$.

Seeds were planted in the greenhouse in a soilless growing medium (Fafard 4P; Conrad Fafard, Inc., Agawam, Mass.) in $4 \times 4-\mathrm{cm}$ transplant trays (LE 1803; Landmark Plastic Corp., Akron, Ohio) for 4 weeks and then field transplanted in early May of each year. Transplants were drenched in a starter fertilizer solution (238 g of $20 \mathrm{~N}-20 \mathrm{P}-20 \mathrm{~K} / 100 \mathrm{~L}$ water) containing insecticide ( $45 \mathrm{~g}$ diazinon $50 \mathrm{WP} / 100$ $\mathrm{L}$ water) for soil insect control.

Experimental units were $6.1-\mathrm{m}$ single beds on 3.1-m centers with 2- to 3-m nonplanted alleys at each end. Plants were spaced $0.6 \mathrm{~m}$ apart within the row. The experiment was a randomized complete block design with 17 cultigens and 4 replications of 10 plants per plot in each of 2 years (1999 and 2000). Plots were used for the purpose of collecting cultigen yield and quality data (Schultheis, 1999, 2000). Pest management practices followed recommended guidelines for North Carolina (North Carolina State University, 2000; Schultheis, 1995). A total of 27 cultigens were evaluated for staminate flower and pollen production. Cultigens and their seed sources are listed in Tables 1 (1999 and 2000) and 2 (1999 or 2000).

Staminate flower production. Flower (and pollen) production data were collected during the peak flowering and fruit setting phase in both years ( 7 to $21 \mathrm{~d}$ after the initial onset of test plot flowering). However, the potential influence of early fruit set on flower production was also evaluated by comparing the flowering levels of each cultigen to their respective proportion of fruit that were mature by the first harvest date. There were three harvest dates in 1999 (19 and 27 July and 6 Aug. 1999); and two harvest dates in 2000 (10 and 25 July 2000).

For all cultigens, open staminate flowers were quantified between 0800 and $1100 \mathrm{HR}$ in each of four plots on four separate days (replicates) in both years at 4-d intervals. These four values were averaged and divided by 40 (total number of plants per cultigen) to obtain the mean number of staminate flowers produced per plant per $\mathrm{d}$ for each cultigen.

Pollen collection and processing. To determine total pollen production, staminate flowers were collected 10 to 30 min before anthesis and placed in screened containers to prevent pollen 
Table 1. Two-year evaluations of staminate flower and pollen grain production by 17 diploid watermelon cultigens. ${ }^{\mathrm{z}}$

\begin{tabular}{|c|c|c|c|c|c|c|c|c|c|}
\hline \multirow[b]{2}{*}{ Cultigen } & \multirow{2}{*}{$\begin{array}{c}\text { Seed } \\
\text { source }^{y}\end{array}$} & \multicolumn{3}{|c|}{ No. staminate flower /plant/d } & \multicolumn{5}{|c|}{ No. pollen grains/staminate flower } \\
\hline & & 1999 & 2000 & Mean $( \pm \mathrm{SE})$ & Min & Max & 1999 & 2000 & Mean $( \pm$ SE $)$ \\
\hline Athens & $\mathrm{NH}$ & 6.5 & 6.0 & $6.2 \pm 0.5$ & 19712 & 46440 & 36545 & 37481 & $37013 \pm 579$ \\
\hline Crimson Sweet & WH & 6.7 & 7.2 & $7.0 \pm 0.4$ & 28352 & 51312 & 35776 & 34282 & $35029 \pm 861$ \\
\hline Delta & SM & 5.8 & 6.8 & $6.3 \pm 0.6$ & 23008 & 50128 & 30125 & 30456 & $30290 \pm 371$ \\
\hline Falcon & SM & 8.2 & 5.9 & $7.1 \pm 0.8$ & 20152 & 40540 & 34717 & 34764 & $34460 \pm 987$ \\
\hline Festival & WH & 5.1 & 5.8 & $5.4 \pm 0.7$ & 19332 & 37172 & 26698 & 26997 & $26848 \pm 517$ \\
\hline Fiesta & SY & 8.6 & 6.8 & $7.7 \pm 0.5$ & 21084 & 37487 & 31380 & 30720 & $30825 \pm 801$ \\
\hline Jamboree & SY & 4.6 & 3.6 & $4.1 \pm 0.6$ & 24152 & 46320 & 32540 & 33216 & $32878 \pm 366$ \\
\hline Mardi Gras & SY & 5.9 & 3.5 & $4.7 \pm 0.6$ & 19864 & 46200 & 30834 & 31941 & $31388 \pm 696$ \\
\hline Margarita & WH & 7.4 & 6.4 & $6.9 \pm 0.7$ & 17656 & 41552 & 26909 & 28927 & $27916 \pm 536$ \\
\hline Pinata-LS & WH & 6.8 & 4.4 & $5.6 \pm 0.7$ & 17153 & 40604 & 28128 & 29587 & $28884 \pm 721$ \\
\hline Regency & SM & 7.8 & 5.8 & $6.8 \pm 0.6$ & 17364 & 45200 & 32463 & 32394 & $32428 \pm 693$ \\
\hline Sentinel & SM & 8.2 & 5.6 & $6.9 \pm 0.7$ & 19080 & 46916 & 36260 & 36318 & $36289 \pm 959$ \\
\hline StarBrite & SM & 6.0 & 4.1 & $5.0 \pm 0.7$ & 19516 & 43072 & 31985 & 32808 & $32396 \pm 387$ \\
\hline StarGazer & SM & 5.9 & 4.4 & $5.2 \pm 0.4$ & 27228 & 42200 & 33685 & 33848 & $33766 \pm 608$ \\
\hline Stars-N-Stripes & SM & 6.9 & 5.5 & $6.2 \pm 0.5$ & 18488 & 40840 & 29393 & 29796 & $29594 \pm 655$ \\
\hline Summer Flavor 800 & $\mathrm{AC}$ & 7.8 & 6.2 & $7.0 \pm 0.7$ & 21040 & 52980 & 37990 & 36754 & $37372 \pm 1289$ \\
\hline WX-24 & WH & 7.5 & 8.0 & $7.8 \pm 0.6$ & 16416 & 41752 & 30224 & 30488 & $30356 \pm 1257$ \\
\hline $\operatorname{LSD}(P=0.05)$ & & & & 1.5 & & & & & 2031 \\
\hline
\end{tabular}

${ }^{2}$ Values are the mean of eight replications. Cultigens are listed alphabetically.

${ }^{y}$ Seed source: $\mathrm{AC}=$ Abbott + Cobb (Feasterville, Pa.), NH = Nunhems (Acampo, Calif.), SM = Seminis (Oxnard, Calif.), SY = Syngenta (Boise, Idaho), and $\mathrm{WH}=$ Willhite (Poolville, Texas).

Table 2. Single-year evaluations of staminate flower and pollen grain production for 10 diploid watermelon cultigens. ${ }^{2}$

\begin{tabular}{|c|c|c|c|c|c|c|}
\hline \multirow[b]{2}{*}{ Cultivar } & \multirow{2}{*}{$\begin{array}{c}\text { Seed } \\
\text { source }^{y}\end{array}$} & \multirow[b]{2}{*}{ Year } & \multirow{2}{*}{$\begin{array}{c}\text { Mean }( \pm \mathrm{SE}) \text { no. staminate } \\
\text { flowers/plant } / \mathrm{d}^{\mathrm{x}}\end{array}$} & \multicolumn{3}{|c|}{ No. pollen grains/staminate flower } \\
\hline & & & & Min & Max & $\operatorname{Mean}( \pm \mathrm{SE})^{\mathrm{x}}$ \\
\hline Celebration & SY & 1999 & $5.8 \pm 0.4$ & 23212 & 45660 & $32617 \pm 550$ \\
\hline Corporal & SM & 1999 & $8.2 \pm 0.4$ & 21752 & 46288 & $32005 \pm 1411$ \\
\hline Dumara & SS & 2000 & $6.1 \pm 0.6$ & 20960 & 36596 & $26258 \pm 1569$ \\
\hline Summer Flavor 500 & $\mathrm{AC}$ & 1999 & $9.0 \pm 0.7$ & 18672 & 43348 & $35783 \pm 779$ \\
\hline Summer Flavor 830 & $\mathrm{AC}$ & 2000 & $6.9 \pm 0.5$ & 20658 & 38982 & $34729 \pm 1967$ \\
\hline Summer Flavor 900 & $\mathrm{AC}$ & 2000 & $7.4 \pm 0.6$ & 20200 & 41800 & $33411 \pm 2889$ \\
\hline Summer Flavor 910 & $\mathrm{AC}$ & 2000 & $6.5 \pm 1.0$ & 19232 & 40940 & $30574 \pm 596$ \\
\hline SWD 8307 & SK & 2000 & $5.4 \pm 0.4$ & 20120 & 38800 & $27795 \pm 1427$ \\
\hline WX-22 & SW & 2000 & $6.0 \pm 0.6$ & 19538 & 38617 & $26559 \pm 811$ \\
\hline XWD 7302 & SK & 1999 & $6.6 \pm 0.7$ & 21712 & 45700 & $32946 \pm 1240$ \\
\hline $\operatorname{LSD}(P=0.05)$ & & & 2.1 & & & 4636 \\
\hline
\end{tabular}

${ }^{\mathrm{z} V a l u e s}$ are the means of four replicates. Cultigens are listed alphabetically.

ySeed source: $\mathrm{AC}=\mathrm{Abbott}+\mathrm{Cobb}($ Feasterville, Pa.), NH = Nunhems (Acampo, Calif.), SK = Sakata (Morgan Hill, Calif.), SM = Seminis Vegetable Seed (Oxnard, Calif.), SW = Southwestern Seed (Casa Grande, Ariz.), SY= Syngenta (Boise, Idaho).

loss from insect visitation. Once corolla expansion and anther dehiscence were confirmed visually with a $10 \times$ hand lens, the corolla was removed using a razor blade and each flower base with anthers was carefully pinched into individual 6-mL snap-cap style polyethylene vials containing $3 \mathrm{ml}$ of a 1:1:2 formalin : $95 \%$ ethanol : $0.9 \%$ saline solution to preserve the pollen grains. Vials were shaken vigorously for 2 min to dislodge pollen grains remaining on and within anthers. The flower base was then removed from the original vial, placed into a second vial containing $2 \mathrm{~mL}$ of the same preservation solution and shaken again to dislodge any pollen grains adhering to the plant tissues. This wash was added back to the original vial. To confirm pollen removal, random samples of removed flower bases and anthers were inspected under a dissecting scope for remaining pollen grains. Very few (0 to 50) pollen grains were found on the surfaces of removed floral tissues or remaining inside dehisced anther sacs. Thus, the shake-and-wash method was considered appropriate for these studies. Twenty randomly chosen flowers from each cultigen were collected and analyzed in each year, five flowers per cultigen on four separate days per year, with cultigen plot chosen randomly within the field on each sampling date.

Pollen quantification. The numbers of pollen grains per flower were quantified using a particle counter (Elzone 180; Particle Data, Elmhurst, Ill.) fitted with a 190- $\mu$ m-diameter aperture (Particle Data, 1987). A detection threshold window $( \pm 10 \mu \mathrm{m})$ of 58 to $78 \mu \mathrm{m}$ was used after obtaining average pollen grain diameter $(68 \mu \mathrm{m})$. Stored pollen samples were filtered through a $100 \mu \mathrm{m}$ polyethylene, macroporous filter (Spectrum Laboratories, Inc., Laguna Hills, Calif.) to remove extraneous plant material. Individual samples were then diluted with saline $(0.9 \% \mathrm{NaCl})$ to a final volume of $20 \mathrm{~mL}$. Estimates of pollen levels were obtained by taking twelve 500- $\mu \mathrm{m}$ subsamples from each whole-flower sample. Subsample values were averaged and multiplied by 40 (total dilution factor) to derive the estimated total number of pollen grains per whole-flower sample. The five whole-flower samples per replication were averaged to obtain replicate means for each cultigen.

The accuracy and precision of particle counter readings were confirmed for random samples using a hemacytometer. Extrapolated totals for pollen grains perflower measurements derived with the hemacytometer were similar to the estimate readings produced electronically $( \pm 5 \%)$. Occasionally, aberrant readings were given by the counter; these were caused by aperture blockage from oversized or oddly shaped particles (e.g., trichome fragments) that were not successfully removed during filtering. Once blockages were removed, counter readings returned to previous, unblocked values. Aberrant readings were omitted from sample estimates.

Male reproductive output. Total pollen production per plant for each cultigen was calculated by multiplying the mean number of staminate flowers produced per plant per $\mathrm{d}$ by the mean number of pollen grains produced per staminate flower. The obtained values provide an index of daily male reproductive output for each cultigen.

Statistical analysis. The experiments were randomized complete blocks with four replications in both years. Staminate flower, pollen production, and male reproductive output were compared using analysis of variance (PROC GLM) and mean separations (PROC MEANS) with SAS version 6.12 (SAS Institute, Cary, N.C.). Pearson $(r)$ correlation analyses were performed to detect possible relationships between early fruit set and flower production (Minitab, 2000).

\section{Results}

Staminateflower production. No significant correlations were detected between early fruit set 


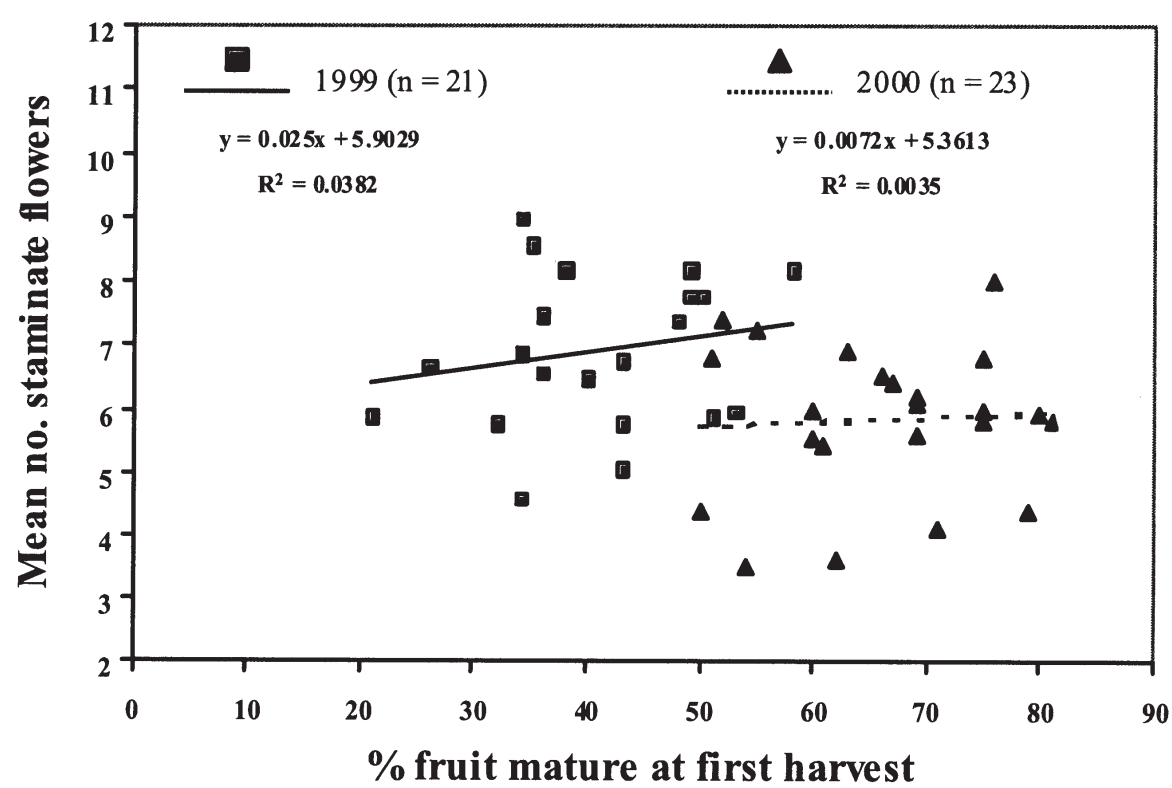

Fig. 1. Relationships between flower production and early fruit set in diploid watermelons.

Table 3. Significance ( $P$ values) of main effects and interactions for flower production, pollen production, and total male reproductive output for 2-year (17 cultigens) and 1-year (10 cultigens) evaluations of diploid watermelons.

\begin{tabular}{lccc}
\hline Effect & $\begin{array}{c}\text { Flower } \\
\text { production }\end{array}$ & $\begin{array}{c}\text { Pollen } \\
\text { production }^{-}\end{array}$ & $\begin{array}{c}\text { Male } \\
\text { reproductive }^{\text {output }^{\mathrm{z}}}\end{array}$ \\
\hline $\begin{array}{l}\text { Cultigens evaluated in both years } \\
\quad \text { Cultigen }\end{array}$ & 0.0006 & $<0.0001$ & $<0.0001$ \\
$\quad$ Year & 0.0029 & 0.4841 & 0.0033 \\
$\quad$ Day (replication) & 0.0225 & 0.5649 & 0.0137 \\
$\quad$ Cultigen $\times$ year & 0.1732 & 0.9959 & 0.1331 \\
$\quad$ Cultigen $\times$ day & 0.9156 & 0.5825 & 0.8254 \\
Cultigens evaluated in single years & \\
$\quad$ Cultigen & 0.0018 & 0.0009 & $<0.0001$ \\
$\quad$ Day (replication) & 0.0236 & 0.9865 & 0.0609 \\
\hline
\end{tabular}

${ }^{\mathrm{z}}$ Male reproductive output $=$ mean number of staminate flowers produced per plant per $\mathrm{d} \times$ mean number of pollen grains produced per staminate flower.

${ }^{\mathrm{y}} 1999$ and 2000.

x1999 or 2000 .

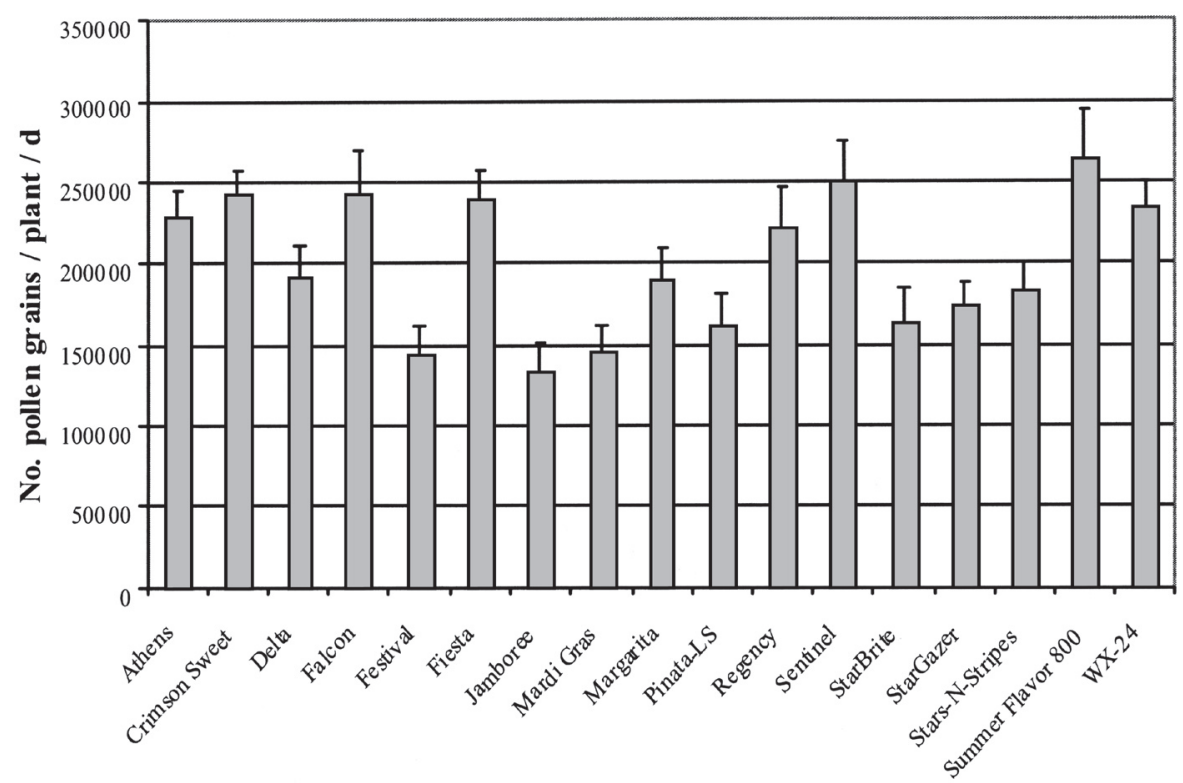

Fig. 2. Male reproductive output (mean \pm SE) for 17 watermelon cultigens evaluated in 1999 and 2000 $(\mathrm{LSD}=47,126)$. and flower production in $1999(r=0.195 ; P=$ $0.396)$ or $2000(r=-0.059 ; P=0.790)$ (Fig. 1$)$. Cultigen had a strong effect on daily staminate flower production for cultigens evaluated in both years $(P=0.0006)$ and for cultigens evaluated in 1999 or $2000(P=0.0018)$ (Table 3). There was also a strong year effect for cultigens tested in both years $(P=0.0029)$, where flower production tended to be greater in 1999 than in 2000 for most cultigens (Table 1); however this trend was not consistent $(P=0.1732)$. In both the 2-year $(P=0.0225)$ and single-year $(P$ $=0.0236)$ evaluations, there were significant replicate (days within years) effects.

Staminate flower production ranged from 3.5 flowers per plant per $\mathrm{d}(\mathrm{f} / \mathrm{p} / \mathrm{d})$ for 'Mardi Gras' (2000; Table 1) to $9.0 \mathrm{f} / \mathrm{p} / \mathrm{d}$ for 'Summer Flavor 500' (1999 only; Table 2). For cultigens evaluated in both years, those consistently producing the most $\mathrm{f} / \mathrm{p} / \mathrm{d}(\geq 6.2)$ were 'Athens', 'Crimson Sweet', 'Delta', 'Falcon', 'Fiesta', 'Margarita', 'Regency', 'Sentinel', 'Stars-NStripes', 'Summer Flavor 800', and 'WX-24'. Cultigens producing the fewest $\mathrm{f} / \mathrm{p} / \mathrm{d}(\leq 5.6)$ were 'Festival', 'Jamboree', 'Mardi Gras', 'PinataLS', 'StarBrite', and 'StarGazer'. In the single year evaluations, 'Corporal', 'Summer Flavor 500 ', and 'Summer Flavor 900' each averaged 7.4 or $m o r e \mathrm{f} / \mathrm{p} / \mathrm{d}$.

Pollen grain production. In both the 2-year $(P<0.0001)$ and single-year $(P=0.0009)$ studies, cultigen had a strong effect on pollen production by individual staminate flowers (Table 3). In contrast to flower production, pollen production was similar between years for cultigens tested in both years $(P=0.4841)$, and between days within years for cultigens tested in both years $(P=0.5649)$ and singleyears $(P=0.9865)$.

For individual flowers, pollen production ranged from 16,416 pollen grains/flower (pg/f) for 'WX-24' to 52,980 pg/f for 'Summer Flavor 800 ' (Table 1). For cultigens evaluated in both years, those consistently producing 36,000 or more pg/f were 'Summer Flavor 800' (37,372), 'Athens' (37,013), and 'Sentinel' (36,289); and those producing the fewest $\mathrm{pg} / \mathrm{f}(<29,000)$ were 'Pinata-LS' $(28,884)$, 'Margarita' $(27,916)$ and 'Festival' $(26,848)$. In the single-year evaluations, only 'Summer Flavor 500' produced more than 35,000 pg/f, and three cultigens ('Dumara', 'SWD 8307', and 'WX-22') each produced $<30,000 \mathrm{pg} / \mathrm{f}$ (Table 2).

Male reproductive output. In the 2-year study, total daily pollen production (number of staminate flowers $\times$ number of pollen grains per flower) differed by cultigen $(P<0.0001)$, year $(P=0.0033)$, and days within years $(P=$ 0.0137) (Table 3 ). The latter two effects (year and replication) are likely due to the differences detected during the staminate flower production analysis.

For cultigens evaluated in both years, total daily pollen production was highest for 'Summer Flavor 800' (264,589 pg/f); however, this value was not statistically different from those of 'Sentinel' (250,876), 'Falcon' $(243,285)$, 'Crimson Sweet' $(243,260)$, 'Fiesta' $(238,911)$, 'WX-24' (234,431), 'Athens' $(229,631)$, and 'Regency' $(222,134)$ (Fig. 2). The lowest total daily pollen production values were obtained 


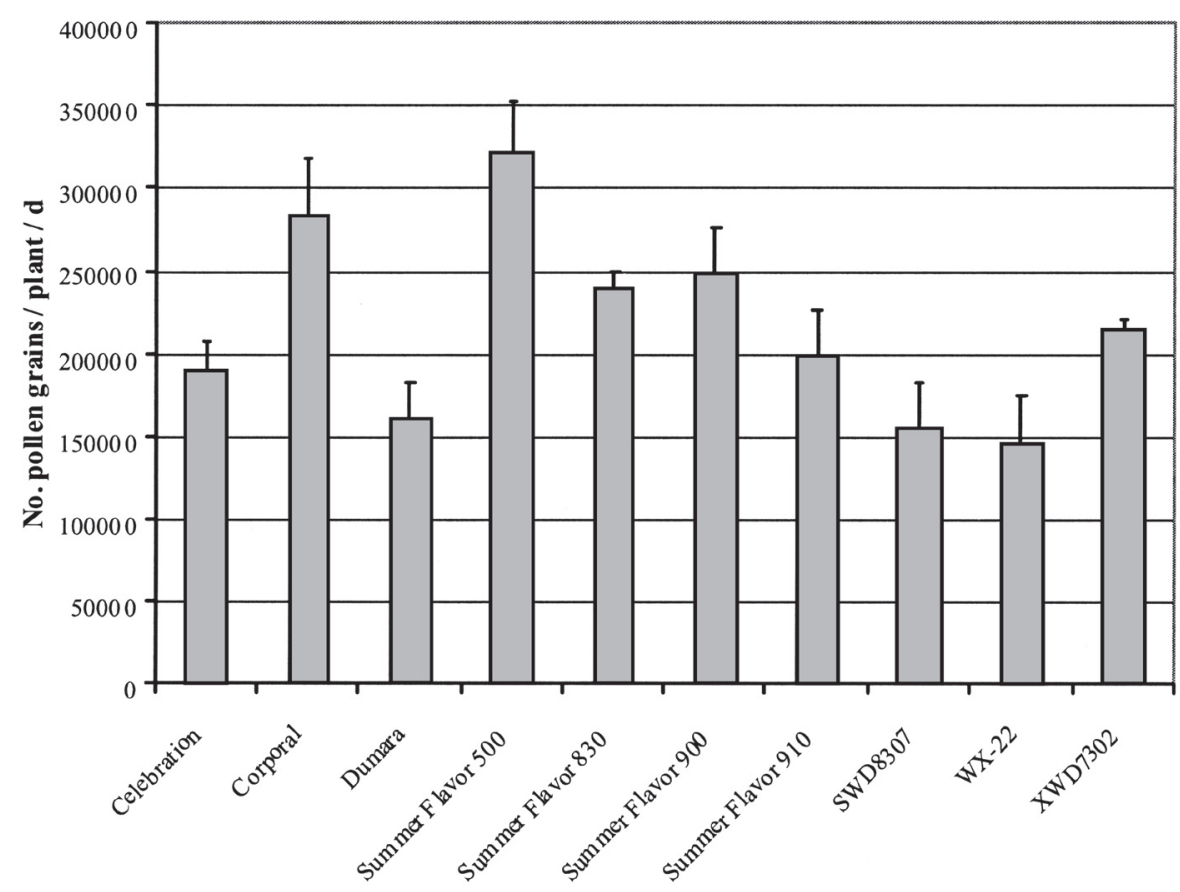

Fig. 3. Male reproductive output (mean \pm SE) for 10 watermelon cultigens evaluated in 1999 or $2000(\mathrm{LSD}=64,234)$.

from 'Jamboree' (134,206 pg/f), 'Festival' $(143,727)$, 'Mardi Gras' $(145,220)$, 'Pinata-LS' $(161,140)$, 'StarBrite' $(163,164)$, 'StarGazer' $(174,295)$, and 'Stars-N-Stripes' $(183,865)$.

A strong cultigen effect $(P<0.0001)$ was also found in the single year study (Fig. 3). Total daily pollen production was highest for'Summer Flavor 500'(321,905 pg/f). The lowest total daily pollen production values $(<200,000 \mathrm{pg} / \mathrm{f})$ were obtained from 'WX-22', 'SWD 8307', 'Dumara', 'Celebration', and 'Summer Flavor 910'.

\section{Discussion}

This study demonstrates the genotypic variability in male reproductive output (staminate flower and pollen grain production) for 27 watermelon cultigens. The data may also serve as a reference for growers when determining which diploid watermelon cultigen(s) to use as pollenizers in triploid watermelon production systems.

Despite variability in pollen production by individual staminate flowers, our results suggest that mean daily pollen grain production per plant may be a relatively stable trait, at least in watermelon. In contrast, daily staminate flower production differed between years and days within years, suggesting that flower production may be more prone to cultural and/or environmental influences such as soil type and moisture, existing fruit load, plant nutrient status, or other factors. While flower production does decrease and eventually cease during watermelon fruit development, we found no relationship between low flowering levels and high early fruit set among the cultigens evaluated. This indicates that our flower production data were collected during initial fruit set and before developing fruit affected flowering levels.

Diploid watermelon cultigens producing the greatest overall number of pollen grains may serve as the best triploid watermelon pollenizers, as, in theory, fewer pollenizer plants would be needed to supply the required quantities of viable pollen to maximize triploid fruit set. A decrease in field space devoted to pollenizer plants would increase the proportion of triploid plants, which, because of their greater consumer demand (Karst, 1990; Marr and Gast, 1991), could increase the overall profit margin of the crop for the grower.

Ultimately, field trials are needed to evaluate the effects of low versus high total pollenproducing pollenizers on triploid watermelon fruit set. However, our hypothesis that overall pollen production may be an important factor to consider when selecting a pollenizer is supported, at least in part, by Fiacchino and Walters (2003), who found that 'Crimson Sweet' was a better pollenizer than 'Fiesta'. Based on our data, the pollen production levels of 'Crimson Sweet' were greater than those found for 'Fiesta'. While these differences were not statistically different, they may be biologically significant, especially considering that only 1,000 pollen grains are needed to set watermelon fruit (Adlerz, 1966).

Two factors for optimizing triploid watermelon production through pollenizer selection that we did not address here, but that we consider equally important to pollen production, are pollenizer flowering phenology and floral attractiveness to pollinators. Therefore, in addition to pollen production, pollenizers that are attractive to bees and have staminate blooming periods that slightly precede or coincide with triploid plant flowering, and that produce sufficient flowers throughout the entire triploid fruit-setting phase, are also important considerations in pollenizer choice. Future work on optimizing pollenizers for triploid watermelon production should address these issues. Wolf et al. (1999) recently demonstrated that different species of
Citrullus differed in their attractiveness to honey bees (Apis mellifera L.), where these differences were due, in part, to variability in nectar sugar concentration among species.

Based on our data and the assumption that pollen production is important in pollenizer selection, the cultigens that we consider the prime candidates as pollenizers (those producing $>220,000$ pollen grains/flower/plant/d) were 'Summer Flavor 800', 'Sentinel', 'Falcon', 'Crimson Sweet', 'Fiesta', 'WX-24', 'Athens', and 'Regency' (Fig. 2). In the single year study (Fig. 3), 'Summer Flavor 500', 'Corporal', 'Summer Flavor 900', and 'Summer Flavor 830 'were also high pollen producers $(>220,000$ pollen grains/flower/plant/d). However, because these cultigens were tested in only 1 year, consistency in flowering and pollen production for these cultigens has not been fully determined.

\section{Literaure Cited}

Adlerz, W.C. 1966. Honey bee visit number and watermelon pollination. J. Econ. Entomol. 59:28-30.

Elmstrom, G.W. and D.N. Maynard. 1992. Attraction of honey bees to watermelon with bee attractant. Proc. Fla. State Hort. Soc. 103:130-133.

Fiacchino, D.C. and S.A. Walters. 2003. Influence of diploid pollinizer frequencies on triploid watermelon quality and yield. HortTechnology 13:58-61.

Karst, T. 1990. Seedless watermelons sure to grow. The Grower 23:61.

Kihara, T. 1951. Triploid watermelons. Proc. Amer. Soc. Hort. Sci. 58:217-230.

Marr, C.W. and K.L.B. Gast. 1991. Reactions by consumers in a farmers' market to prices for seedless watermelon and ratings of eating quality. HortTechnology 1:105-106.

Maynard, D.N. and G.W. Elmstrom. 1990. Triploid watermelon production practices and varieties. Acta Hort. 318:169-173.

Minitab, Inc. 2000. User's guide, release 13. Minitab, Inc., State College, Pa.

NeSmith, S. and J. Duval. 2001. Fruit set of triploid watermelons as a function of distance from a diploid pollinizer. HortScience 36:60-61.

North Carolina State University. 2000. The 1999 North Carolina agricultural chemical manual. N.C. State Univ. College Agr. Life Sci., Raleigh.

North Carolina Agricultural Research Service, North Carolina Dept. of Agriculture, and United States Dept. of Agriculture. 1981. Soils of the Central Crops Research Station, North Carolina: Their technical and usability classification. N.C. State Univ. Soil Sci. Dept.

Particle Data. 1987. Elzone 180 Instruction manual. Particle Data, Inc. Elmhurst, Ill.

Rhodes, B., K.B. Gruene, and W.M. Hood. 1997. Honey bees waste time on triploid male flowers. Cucurbit Genet. Coop. Rpt. 20: 45.

Robinson, R.W. and D.S. Decker-Walters. 1997. Cucurbits. CAB Intl., Wallingford, U.K.

Schultheis, J.R. 1995. Commercial watermelon production. N.C. Coop. Ext. Serv. Hort. Info. Lflt. 30.

Schultheis, J.R. 1999. 1999 Cucurbit and sweet corn cultivar evaluations: Watermelon report. N.C. State Univ. Hort. Res. Ser. 136.

Schultheis, J.R. 2000. 2000 Cucurbit and sweet corn cultivar evaluations: Watermelon report. N.C. State Univ. Hort. Res. Ser. 137.

Wolf, S., Y. Lensky, and N. Paldi. 1999. Genetic variability in flower attractiveness to honeybees (Apis mellifera L.) within the genus Citrullus. HortScience 34:860-863. 